\title{
Automatic Filterization For Industrial Drinking Water Quality Based On Internet Of Things
}

\section{Sistem Monitoring Filterisasi Air Minum Industri Berbasis Internet Of Things}

\author{
${ }^{1}$ Alivia Novita Andari, ${ }^{2}$ Elta Sonalitha, ${ }^{3}$ Subairi \\ [alivianvt@gmail.com ${ }^{1}$, elta.sonalitha@unmer.ac.id ${ }^{2}$,subairi@unmer.ac.id ${ }^{3}$ ] \\ ${ }^{1}$ Program Studi Teknik Elektro,Fakultas Teknik,Universitas Merdeka Malang
}

\begin{abstract}
Water that suitable for consumption must comply with several biological, chemical and radioactive requirements. The majority of people not understand the quality of the water they consume, most people only recognize clean and dirty water, without knowing the suitability of this water. Because not all substances contained in water can be seen with the naked eye, so it will be difficult to know whether the water is in accordance with the quality of drinking water or not. This study was aimed at monitoring several drinking water quality parameters in the form of pH (6.5 - 8.5), Turbidity $(<5 \mathrm{NTU})$ temperature $\left(22{ }^{\circ} \mathrm{C}-27{ }^{\circ} \mathrm{C}\right)$ and TDS (<500 ppm) using pH sensors, turbidity sensors temperature sensors and TDS sensors, and Ultraviolet light as an inhibitor of bacterial growth. The resulting data is executed by NodeMCU 8266 and forwarded via IoT to be sent to the server and forwarded to the application automatically. The results of the $\mathrm{pH}$ sensor readings show a reading accuracy of up to $98.36 \%$, the temperature sensor the reading accuracy reaches $96 \%$, the turbidity sensor has an accuracy level of up to $90.1 \%$, while the TDS (Total Dissolve Solid) sensor has an accuracy level of $95,16 \%$. Water from the filtration of the water filter can be categorized as suitable for consumption accordance with drinking water standards in the Decree of the Minister of Health No.492 of 2010.
\end{abstract}

Keywords - filtration of water; sensors; monitoring.

\begin{abstract}
Abstrak. Air yang layak untuk diminum harus sesuai beberapa persayaratan biologis, kimia dan radioaktif. Mayoritas masyarakat kurang mengerti mengenai kualitas air minum, mereka hanya mengerti tentang air bersih dan air kotor saja. Hal ini dikarenakan zat yang terkandung dalam air minum merupakan mikroskopis. Penelitian ini ditujukan untuk melakukan monitoring beberapa parameter kualitas air minum berupa $P h(6,5-8,5)$, Kekeruhan $(<5$ NTU) suhu $\left(22^{\circ} \mathrm{C}-27^{\circ} \mathrm{C}\right)$ serta TDS $(<500 \mathrm{ppm})$ dengan menggunakan sensor suhu,sensor $\mathrm{pH}$, sensor kekeruhan dan sensor $T D S$ dan nyala lampu ultraviolet sebagai penghambat pertumbuhan bakteri. Data yang dihasilkan diproses oleh NodeMCU 8266 dan diproses melalui IoT untuk ditampilkan ke aplikasi secara otomatis. Hasil pembacaan sensor pH menunjukkan tingkat akurasi pembacaan hingga 98,36\%, pada sensor suhu keakurasian pembacaan mencapai 96\%, pada sensor kekeruhan memiliki tingkat keakurasian hingga 90,1\%, seddangkan pada sensor TDS (Total Dissolve Solid) memiliki tingkat keakurasian sebesar 95,16\%. Air hasil filtrasi alat filter air dapat dikategorikan layak untuk diminum sesuai dengan standar air minum dalam keputusan Menteri kesehatan No.492 tahun 2010.
\end{abstract}

Kata kunci - Air minum hasil filtrasi; Sensor; monitoring.

\section{PENDAHULUAN}

Air adalah salah satu kebutuhan utama bagi makhluk hidup dan seluruh lini kehidupan. Kebutuhan air untuk tubuh manusia sebanyak 2 liter seiap hari. Berdasarkan Keputusan Menteri Kesehatan No.492 Tahun 2010. Air yang layak untuk diminum harus sesuai dengan persayaratan biologis,kimia dan radioaktif yang ada di beberapa parameter. Mayoritas masyarakat hanya mengetahui tentang air bersih dan air kotor. Terkait banyaknya zat yg terlarut didalam air yang mikroskopis maka untuk mengetahui kualitas air minum susah diketahui oleh masyarakat.

Beberapa parameter seperti suhu pada rentang $22^{\circ} \mathrm{c}-27^{\circ} \mathrm{c}, \mathrm{pH}$ pada rentang $6,5-8,5$,kekeruhan kurang dari $5 \mathrm{NTU}$ dan banyaknya zat yang terlarut kurang dari 500 ppm, hal ini berpengaruh terhadap kualitas air minum. Dengan berkembangnya teknologi,pengolahan air bersih memiliki banyak cara salah satunya menggunakan filterisasi air[1].

Saat ini banyak metode untuk filterisasi air minum rumah tangga salah satunya dengan 4 tahap filter. Air minum sendiri merupakan hal yang sangat dibutuhkan bagi tubuh manusia. Aplikasi yang digunakan dapat membaca hasil percobaan secara real time,dan mampu menyimpan hasil pembacaan sensor kualitas air sehingga pengguna dapat melihat kualitas air minum.

\section{A. NodeMCU ESP 8266}

NodeMCU ESP8266 merupakan salah satu perangkat pendukung IoT (Internet Of Things). Berdasarkan pada penelitian maka, pin yang digunakan merupakan pin analog dimana terdapat pada pin A0. Namun, pada ESP 82 
hanya memiliki 1 pin analog sehingga dibutuhkan multiplexer yang digunakan sebagai tambahan pin analog[3].

\section{B. Filterisasi Air}

Terdapat beberapa proses penyaringan air yang sudah melalui tahap penyaringan yang dapat diminum oleh masyarakat. Akan tetapi tidak semua tahapan ini dilakukan oleh pengelola air, tahapan ini dapat dilakukan tergantung dari mana sumber air berasal[6]. Tahap filterisasi air terdiri dari beberapa proses, yaitu:

\section{a. Unit Penampungan}

Pada bagian ini berfungsi sebagai penampungan air.

b. Unit Filterisasi

Saat di tahap ini air akan di proses melalui beberapa tahapan yakni :

1. Tahap Koagulasi

2. Tahap Flokulasi

3. Tahap Pengendapan (Sedimentation)

4. Tahap Penyaringan (Filtration)

5. Tahap Penampungan Akhir

Air yang sudah sampai di tahap ini menandakan bahwa air tersebut siap diminum oleh masyarakat.

\section{PureIt}

Air merupakan kebutuhan utama bagi manusia. Dengan faktor tersebut PT Unliver Indonesia meluncurkan Produk PureIt. PureIt adalah suatu rancangan produk yang dapat memurnikan air tanpa menggunakan listrik dan tanpa menggunakan gas. Air yang dimasukkan ke dalam PureIt dapat diproses tanpa harus dimasak terlebih dahulu[7].

\section{Sensor Suhu}

Sensor suhu berfungsi sebagai pendeteksi perubahan suhu pada cairan yang diuji. Sensor suhu dapat mendeteksi perubahan tinggi nya suhu dalam bentuk analog maupun digital. Komponen ini mengubah besaran panas pada cairan menjadi besaran listrik dalam bentuk digital[1].

\section{E. Sensor $\mathbf{p H}$}

$\mathrm{pH}$ merupakan besarnya derajat asam atau basa sebuah objek. Sensor $\mathrm{pH}$ berfungsi untuk menguji derajat keasaman sebuah larutan. Besaran nilai $\mathrm{pH}$ dari 0 hingga 14. Metode pembacaan sensor $\mathrm{pH}$ adalah dengan membaca level tegangan[1].

\section{F. Sensor Kekeruhan}

Sensor kekeruhan air mendeteksi kualitas air melalui pengukuran level dari turbidity. Alat ini bekerja dengan menggunakan cahaya untuk mendeteksi partikel tersuspensi dalam air dengan mengukur tingkat transmitansi dan hamburan cahaya, yang berubah dengan jumlah padatan tersuspensi total dalam air. Ketika nilai meningkat, maka level turbidity air juga meningkat. Sensor keekruhan bekerja pada tegangan $5 \mathrm{~V}$, sensor kekeruhan memiliki 2 metode output yakni analog output berupa level tegangan antara $0-4.5 \mathrm{~V}$ dan digital output berupa level tinggi dan rendahnya sinyal[1].

\section{G. Sensor TDS (Total Dissolve Solid)}

Banyaknya zat terlarut dalam sebuah larutan dapat diukur menggunakan sensor TDS. TDS meter merupakan sebuah alat untuk mengukur zat terlarut dalam PPM (Part Per Million). [13] Digunakan untuk mengetahui kualitas air baik untuk pengairan,kualitas air dalam aquarium, kadar air dalam kolam renang, kualitas air mineral, dll[6].

\section{H. Lampu Ultraviolet}

Lampu ultraviolet tidak hanya menghasilkan sinar ultraviolet namun bisa digunakan untuk desinfektan. Gelombang yang digunakan yakni dengan panjang gelombang UV-C ( $\pm 200 \mathrm{~nm}-300 \mathrm{~nm})[1]$.

\section{Internet Of Things (IoT)}

Internet Of Things (IoT) merupakan sebuah teknologi yang memungkinkan adanya sebuah pengendalian, komunikasi kerjasama dengan berbagai perangkat keras dan data melalui jaringan internet. Dimana IoT berfungsi sebagai proses menyambungakn sesuatu yang tidak dioperasikan oleh manusia ke internet[9].

\section{METODE}

Data yang diambil dalam pengujian eksperimental ini adalah untuk mengetahui kualitas air minum di dengan menggunakan beberapa sensor yakni sensor suhu,pH,kekeruhan dan TDS (Total Dissolve System). Pengujian dan pengambilan data dilakukan dengan membaca hasil pembacaan sensor yang dapat dilihat di aplikasi yang telah dibuat. 
Adapun pengujian dan pengambilan data yang akan dilakukan yaitu :

1. Pengujian A merupakan pengujian dan pengambilan data yang pertama pada masing - masing sensor berdasarkan data yang telah terbaca di aplikasi. Hasil pembacaan data ditampilkan dalam bentuk tabel.

2. Pengujian B merupakan pengujian dan pengambilan data yang kedua pada masing - masing sensor menggunakan sensor digital. Hasil pembacaan data ditampilkan dalam bentuk tabel.

\section{HASIL DAN PEMBAHASAN}

Pengujian yang dilakukan memiliki tujuan untuk mengetahui kualitas air minum yang dapat diminum berdasarkan pengujian pada beberapa sensor. Sehingga dapat diambil kesimpulan mengenai kualitas air minum. Pengujian dilakukan dengan menggunakan alat yang telah dirancang yang beralamat di Kos Putri Muslimah Jatimulyo Lowokwaru Kota Malang.

\section{A. Hasil Perancangan Aplikasi}

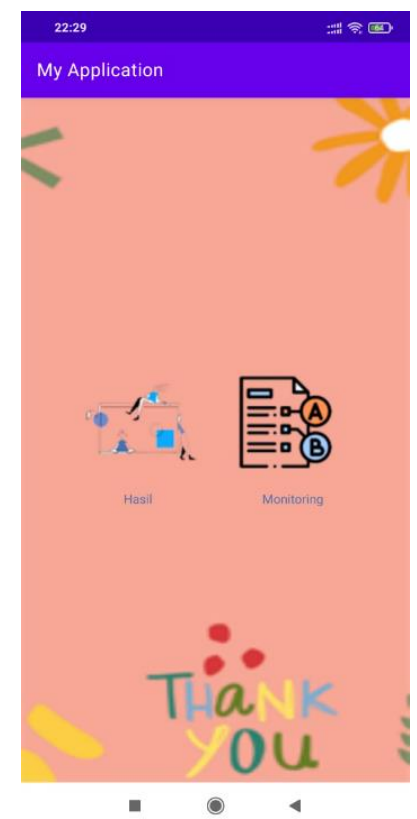

Gambar 1. Tampilan beranda aplikasi

Berdasarkan gambar 1 dapat diketahui bahwa pada menu aplikasi terdapat 2 sub menu yakni menu monitoring dan menu hasil.

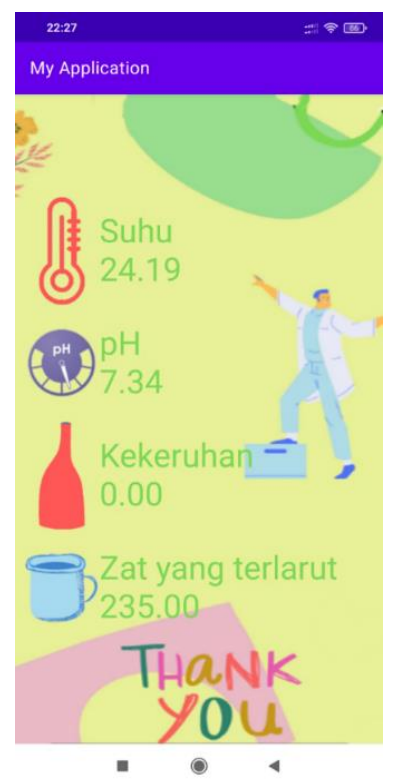

Gambar 2. Tampilan menu monitoring 
Berdasarkan gambar 2 dapat diketahui bahwa pada menu monitoring menunjukkan hasil dari monitoring yang dihasilkan yaitu suhu,pH,kekeruhan dan zat terlarut. Pembacaan data sesuai dengan kualitas air yang dihasilkan.

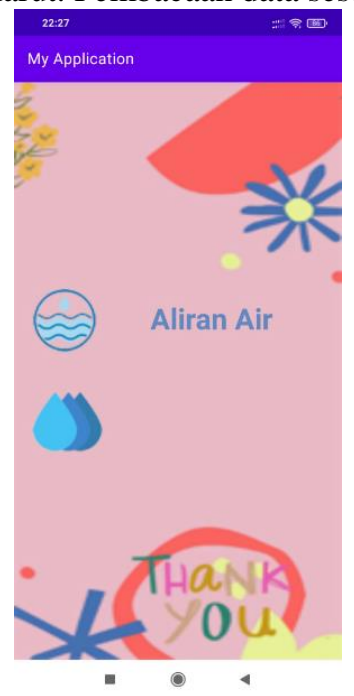

Gambar 3. Tampilan menu hasil

Berdasarkan gambar 3 dapat diketahui bahwa pada menu hasil dapat diketahui apabila terdapat air yang berada PureIt dan air yang dihasilkan layak untuk diminum atau tidak.

\section{B. Hasil Pengujian System}

Pengujian akurasi Sensor pH

Tabel 1 Hasil Pengujian Sensor pH

\begin{tabular}{|c|c|c|c|c|}
\hline \multirow[b]{2}{*}{$\begin{array}{c}\text { Percobaan } \\
\text { ke- }\end{array}$} & \multicolumn{2}{|c|}{ Nilai $\mathrm{pH}$} & \multirow[b]{2}{*}{$\begin{array}{c}\text { Deviasi } \\
\text { Kesalahan }\end{array}$} & \multirow[b]{2}{*}{$\begin{array}{c}\text { Nilai Keberhasilan } \\
\text { (\%) }\end{array}$} \\
\hline & $\begin{array}{c}\mathrm{pH} \text { meter } \\
\text { digital }\end{array}$ & $\begin{array}{c}\text { Sensor } \\
\mathrm{pH}\end{array}$ & & \\
\hline 1 & 7 & 7 & 0 & 100 \\
\hline 2 & 7 & 7 & 0 & 100 \\
\hline 3 & 7 & 7 & 0 & 100 \\
\hline 4 & 7 & 7 & 0 & 100 \\
\hline 5 & 7 & 7,1 & 0,1 & 98,6 \\
\hline 6 & 7 & 7,1 & 0,1 & 98,6 \\
\hline 7 & 7 & 7,2 & 0,2 & 97,3 \\
\hline 8 & 7 & 7,2 & 0,2 & 97,3 \\
\hline 9 & 7 & 7,3 & 0,3 & 95,9 \\
\hline 10 & 7 & 7,3 & 0,3 & 95,9 \\
\hline \multicolumn{3}{|c|}{ Rata - Rata } & 0,12 & 98,36 \\
\hline
\end{tabular}

Berdasarkan pada Tabel 1 dapat diketahui bahwa sensor $\mathrm{pH}$ memiliki tingkat keakurasian pembacaan data hinga $98,36 \%$

Pengujian akurasi Sensor suhu

Tabel 2 Hasil Pengujian Sensor Suhu

\begin{tabular}{|c|c|c|c|c|c|}
\hline \multirow{2}{*}{$\begin{array}{c}\text { Percobaan } \\
\text { ke- }\end{array}$} & \multirow{2}{*}{$\begin{array}{l}\text { Waktu } \\
\text { (Jam) }\end{array}$} & \multicolumn{2}{|c|}{ Nilai Suhu Air } & \multirow{2}{*}{$\begin{array}{c}\text { Deviasi } \\
\text { Kesalahan }\end{array}$} & \multirow{2}{*}{$\begin{array}{c}\text { Presentase } \\
\text { Keberhasilan (\%) }\end{array}$} \\
\hline & & $\begin{array}{l}\text { Termometer } \\
\text { Alkohol }\end{array}$ & $\begin{array}{l}\text { Sensor } \\
\text { Suhu }\end{array}$ & & \\
\hline 1 & 09.05 & 22 & 21 & 1 & 95,6 \\
\hline 2 & 09.10 & 22 & 21 & 1 & 95,6 \\
\hline 3 & 09.15 & 22 & 21 & 1 & 95,6 \\
\hline 4 & 09.20 & 22 & 22 & 0 & 100 \\
\hline 5 & 09.25 & 22 & 22 & 0 & 100 \\
\hline 6 & 12.25 & 25,2 & 23,9 & 1,3 & 94,56 \\
\hline 7 & 12.30 & 25,2 & 23,9 & 1,3 & 94,56 \\
\hline 8 & 12.40 & 25,2 & 24 & 1,2 & 95 \\
\hline 9 & 12.50 & 25,2 & 24 & 1,2 & 95 \\
\hline 10 & 13.15 & 25,2 & 24 & 1,2 & 95 \\
\hline \multicolumn{4}{|c|}{ Rata - Rata } & 0,92 & 96,092 \\
\hline
\end{tabular}


Berdasarkan pada Tabel 2 dapat diketahui bahwa sensor suhu memiliki tingkat keakurasian pembacaan data hingga 96,062\%.

1. Pengujian akurasi Sensor kekeruhan

Tabel 3 Hasil Pengujian Sensor Kekeruhan

\begin{tabular}{|c|c|c|c|c|}
\hline $\begin{array}{l}\text { Percobaan } \\
\text { ke- }\end{array}$ & $\begin{array}{l}\text { Turbidity } \\
\text { Meter }\end{array}$ & $\begin{array}{l}\text { Sensor } \\
\text { Kekeruhan }\end{array}$ & $\begin{array}{l}\text { Deviasi } \\
\text { Kesalahan }\end{array}$ & $\begin{array}{l}\text { Keberhasilan } \\
(\%)\end{array}$ \\
\hline 1 & 1,15 & 1 & 0,15 & 86,9 \\
\hline 2 & 1,05 & 1 & 0,05 & 95,23 \\
\hline 3 & 0,85 & 0,75 & 0,1 & 88,23 \\
\hline 4 & 0,825 & 0,75 & 0,075 & 90,9 \\
\hline 5 & 0,565 & 0,5 & 0,065 & 88,5 \\
\hline 6 & 0,575 & 0,5 & 0,075 & 86,9 \\
\hline 7 & 0,66 & 0,6 & 0,06 & 90,9 \\
\hline 8 & 0,66 & 0 & 0,66 & 100 \\
\hline 9 & 0,66 & 0 & 0,66 & 100 \\
\hline 10 & 0,66 & 0 & 0,66 & 100 \\
\hline \multicolumn{5}{|r}{ Rata - Rata } \\
\hline
\end{tabular}

Berdasarkan pada Tabel 3 dapat diketahui bahwa sensor kekeruhan memiliki tingkat keakurasian pembacaan data hingga $91 \%$.

2. Pengujian akurasi Sensor TDS (Total Dissolve System)

Tabel 4 Hasil Pengujian Sensor Kekeruhan

\begin{tabular}{|c|c|c|c|c|}
\hline $\begin{array}{c}\text { Percobaan } \\
\text { Ke- }\end{array}$ & $\begin{array}{l}\text { TDS Meter } \\
(\mathrm{ppm})\end{array}$ & $\begin{array}{c}\text { Sensor TDS } \\
(\mathrm{ppm})\end{array}$ & $\begin{array}{c}\text { Deviasi } \\
\text { Kesalahan } \\
\end{array}$ & Keberhasilan(\%) \\
\hline 1 & 340 & 310 & 30 & 91,2 \\
\hline 2 & 340 & 320 & 20 & 94,12 \\
\hline 3 & 340 & 330 & 10 & 97,1 \\
\hline 4 & 340 & 340 & 0 & 100 \\
\hline 5 & 340 & 340 & 0 & 100 \\
\hline 6 & 444 & 200 & 244 & 45 \\
\hline 7 & 427 & 217 & 210 & 50,8 \\
\hline 8 & 453 & 191 & 262 & 42,16 \\
\hline 9 & 459 & 191 & 268 & 41,6 \\
\hline 10 & 469 & 191 & 278 & 40,8 \\
\hline \multicolumn{3}{|c|}{ Rata - Rata } & 132,2 & 70,278 \\
\hline
\end{tabular}

Berdasarkan pada Tabel 4 dapat diketahui bahwa sensor Total Dissolve System memiliki tingkat keakurasian pembacaan data hingga 96,19\%.

\section{KESIMPULAN}

Sensor pH memiliki tingkat keakurasian pembacaan data hinga 98,36\%. Sensor suhu memiliki tingkat keakurasian pembacaan data hingga 96,062\%. Sensor kekeruhan memiliki tingkat keakurasian pembacaan data hingga $91 \%$. Sensor Total Dissolve System memiliki tingkat keakurasian pembacaan data hingga 96,19\%. Berdasarkan pengujian yang dilakukan didapatkan rata rata hasil pembacaan data sebesar $90 \%$ dengan eror sebesar $\pm 10 \%$. Air hasil filtrasi otomatis menandakan layak minum sesuai dengan parameter yang ditentukan dan sesuai dengan peraturan Keputusan Menteri Kesehatan No. 492 Tahun 2010.

\section{UCAPAN TERIMAKASIH}

Sembah sujud serta puji dan syukurku pada-Mu Allah SWT. Tuhan semesta alam yang menciptakanku dengan bekal yang begitu teramat sempurna. Taburan cinta, kasih sayang, rahmat dan hidayat-Mu telah memberikan ku kekuatan, kesehatan, semangat pantang menyerah dan memberkatiku dengan ilmu pengetahuan serta cinta yang pasti ada disetiap ummat-Mu. Atas karunia serta kemudahan yang Engkau berikan akhirnya Tugas Akhir ini dapat terselesaikan. Sholawat dan salam selalu ku limpahkan kepada Rasulullah Muhammad SAW. Persembahan Tugas Akhir ini untuk orang tercinta dan tersayang atas kasihanya yang berlimpah.

1. Terimakasih untuk diri saya sendiri karena sudah melewati semuanya sendirian

2. Terimakasih untuk ayah dan ibu yang selalu mendukung keputusan saya dengan segala do'a , kasih sayang dan materi

3. Teman - teman Telekomunikasi 2015 atas segala bantuannya

4. Dan terimakasih untuk semua teman teman yang telah mendukung dalam keadaan suka dan duka 


\section{REFERENSI}

[1]. U. P. D. Arindita, H. Hudiono, and F. A. Soelistianto, "RANCANG BANGUN SISTEM FILTERISASI UNTUK MONITORING KUALITAS AIR MINUM RUMAH TANGGA,” J. Jartel J. Jar. Telekomun., vol. 8 , no. 1, p. 7, 2019.

[2]. M. A. Nugroho and M. Rivai, "Sistem Kontrol dan Monitoring Kadar Amonia untuk Budidaya Ikan yang Diimplementasi pada Raspberry Pi 3B," J. Tek. ITS, vol. 7, no. 2, pp. 3-8, 2019, doi: 10.12962/j23373539.v7i2.30920.

[3]. E. E. Barus, R. K. Pingak, and A. C. Louk, “OTOMATISASI SISTEM KONTROL pH DAN INFORMASI SUHU PADA AKUARIUM MENGGUNAKAN ARDUINO UNO DAN RASPBERRY PI 3,” J. Fis. Fis. Sains dan Apl., vol. 3, no. 2, pp. 117-125, 2018, doi: 10.35508/fisa.v3i2.612.

[4]. A. G. L. Boro, A. B. Setiawan, and W. Dirgantara, "Penjadwalan Pakan Dan Pengendalian Suhu Pada Kandang Babi Secara Otomatis Berbasis Arduino (Automatic Feeding Schedule And Temperature Controlling In Pig Cage Based On Arduino)," JEEE-U (Journal Electr. Electron. Eng., vol. 3, no. 2, pp. 264 $278,2019$.

[5]. V. Isnainy, E. S. Budi, and H. Hardjono, "Pengontrolan pH Menggunakan Algoritma Logika Fuzzy pada Pengolahan Limbah Cairan Kimia,” J. Elektron. dan Otomasi Ind., vol. 4, no. 3, pp. 39-44, 2020.

[6]. D. A. Ula, "Rancang bangun sistem monitoring kualitas air layak minum berbasis internet of things dengan metode Fuzzy Tsukamoto sebagai sistem pendukung keputusan.” Universitas Islam Negeri Maulana Malik Ibrahim, 2020.

[7]. P. U. Indonesia, "No Title," Pureit \#GivePureLove, 2017. https://www.unilever.co.id/news/pressreleases/2017/pureit-givepurelove.html (accessed Feb. 03, 2021).

[8]. F. Budiman, M. Rivai, and M. A. Nugroho, "Monitoring and Control System for Ammonia and pH Levels for Fish Cultivation Implemented on Raspberry Pi 3B," in 2019 International Seminar on Intelligent Technology and Its Applications (ISITIA), 2019, pp. 68-73.

[9]. S. A. Kurniatuty and K. A. Widodo, "Rancang Bangun Sistem Kontrol Pakan Ikan dan Kekeruhan Air yang Dilengkapi Dengan Monitoring Kualitas Air Berbasis Internet of Things ( IoT )," Informatika, vol. 02, no. 01, pp. 1-5, 2015. 